\title{
Clinical Study \\ High Dose of Lamivudine and Resistance in Patients with Chronic Hepatitis B
}

\author{
Hamid Ullah Wani, Saad Al Kaabi, Manik Sharma, Rajvir Singh, Anil John, \\ Moutaz Derbala, and Muneera J. Al-Mohannadi \\ Department of Medicine, Division of Gastroenterology, Hamad Medical Corporation (HMC), 2 South 2, P.O. Box 3050, Doha, Qatar
}

Correspondence should be addressed to Hamid Ullah Wani; doch95@yahoo.com

Received 16 June 2014; Revised 10 August 2014; Accepted 28 August 2014; Published 30 September 2014

Academic Editor: Piero Luigi Almasio

Copyright (C) 2014 Hamid Ullah Wani et al. This is an open access article distributed under the Creative Commons Attribution License, which permits unrestricted use, distribution, and reproduction in any medium, provided the original work is properly cited.

Background. Lamivudine is the most affordable drug used for chronic hepatitis B and has a high safety profile. With the daily dose of $100 \mathrm{mg}$ there is progressive appearance of resistance to lamivudine therapy. In our study we used $150 \mathrm{mg}$ of lamivudine daily as a standard dose which warrants further exploration for the efficacy of the drug. Aims of the Study. To assess the efficacy of lamivudine $150 \mathrm{mg}$ daily on resistance in patients with chronic hepatitis B. Methods. This retrospective study consists of 53 patients with chronic hepatitis B treated with $150 \mathrm{mg}$ of lamivudine daily. The biochemical and virological response to the treatment were recorded at a 1-year and 2-, 3-, 4-, and 5-year period and time of emergence of resistance to the treatment was noted. Results. The mean age of the patients was 54 years with $80 \%$ being males. The resistance to lamivudine $150 \mathrm{mg}$ daily at 1 year and 2,3 , and 5 years was $12.5 \%, 22.5 \%, 37.5 \%$, and $60 \%$, respectively, which is much less compared to the standard dose of $100 \mathrm{mg}$ of lamivudine. Conclusions. Lamivudine is safe and a higher dose of $150 \mathrm{mg}$ daily delays the resistance in patients with chronic hepatitis B.

\section{Introduction}

Chronic hepatitis B remains the most common serious health problem in the world, especially in the Asia Pacific region. Worldwide, there are 350 million people with chronic carrier of HBV. Treatment of HBV is relatively safe and easy compared to hepatitis $\mathrm{C}$ treatment, but the drug resistance is the main problem. The lamivudine and telbivudine are prone to develop resistance rapidly. Since the introduction of lamivudine, treatment of chronic hepatitis B has been characterized by a rapid increase in the number of available antiviral drugs, all belonging to the class of HBV polymerase inhibitors. Due to better tolerance and more convenient administration compared to interferon, HBV polymerase inhibitors today account for the vast majority of prescribed therapies for chronic hepatitis B in Western countries $[1,2]$. However, longterm suppression of HBV is needed, particularly in HBeAgnegative patients harboring the precore mutant.

Lamivudine (LAM) was the first approved HBV polymerase inhibitor. It is characterized by good clinical tolerability, moderate antiviral efficacy, and rather quick development of resistance. Approximately $20 \%$ of patients treated with LAM develop resistance to LAM by 1 year and $70 \%$ to $80 \%$ by 5 years after the start of treatment [3].

Preliminary data indicate that the development of multiple lamivudine associated mutations may even reduce the efficacy of tenofovir therapy [4]. However, we have a good number of patients who are on lamivudine therapy with excellent viral response who need a continuous followup to observe the development of LAM resistance.

The clinical endpoints of chronic hepatitis B treatment are still not well defined $[5,6]$. In $\mathrm{HBeAg}$-positive patients, $\mathrm{HBeAg}$ seroconversion has been shown to be associated with a reduction in liver-associated morbidity and increased survival [7]. Thus, HBeAg seroconversion is considered a clinical endpoint in this group of patient population and discontinuation of $\mathrm{HBV}$ polymerase inhibitors is recommended 6-12 months after $\mathrm{HBeAg}$ seroconversion in patients who have not developed liver cirrhosis [8-10]. Treatment endpoints in $\mathrm{HBeAg-negative} \mathrm{hepatitis} \mathrm{B} \mathrm{in} \mathrm{most} \mathrm{cases} \mathrm{are} \mathrm{restricted} \mathrm{to}$ sustained normalization of ALT levels and suppression of HBV DNA, as HBsAg seroconversion is rare with current 
treatment options [3, 7]. Consequently, treatment duration and endpoints are more difficult to define in these patients. Most guidelines therefore recommend indefinite treatment of patients with $\mathrm{HBeAg-negative} \mathrm{chronic} \mathrm{hepatitis} \mathrm{B.}$

\section{Materials and Methods}

This retrospective study included 53 patients with chronic hepatitis B who were on lamivudine treatment since June 2005 at the Department of Gastroenterology, Hamad Medical Corporation. Before the start of lamivudine treatment all patients were HBsAg positive, had detectable levels of $\mathrm{HBV}$ DNA level $>5$ to $10 \log$ copies/mL, and had elevated liver enzymes about 3 to 5 times the upper limit of normal. All patients received lamivudine in a single daily dose of $150 \mathrm{mg}$.

The patients with the following conditions were excluded from the study:

(1) coinfection with hepatitis $C$, hepatitis D, and human immunodeficiency virus,

(2) association with other forms of liver diseases, such as alcoholic liver disease, drug-induced hepatitis, or autoimmune hepatitis,

(3) previous treatment of $\mathrm{HBV}$ with interferon and nucleos(t)ide analogs other than LAM.

The patients who did not have a regular followup on the medical records and the patients who had no clinical and laboratory assessments at regular intervals were excluded.

All of these patients had a followup after every 3 to 6 months with routine biochemical liver function tests and serum HBV DNA levels. Serum HBV DNA levels were quantified at baseline and at each follow-up visit using the COBAS Ampli Prep or COBAS Taqman HBV test (Roche Molecular System) [11, 12].

The (i) biochemical response (normalization of serum alanine aminotransferase (ALT) level), (ii) complete virological response (undetectable serum HBV DNA by realtime polymerase chain reaction, $<100$ copies $/ \mathrm{mL}$ ), and (iii) virological breakthrough were recorded in all patients. Out of 50 patients, 40 patients had a regular five-year followup available in the medical records.

Virological breakthrough was defined as an increase in serum HBV DNA of more than $1 \log$ copies/mL from the nadir of the initial response. A flare-up of hepatitis was defined as an increase in ALT level to more than 3 times the upper limit of normal.

In this study we do not have molecular studies available for lamivudine resistance. The time of "virological breakthrough" and "flare-up" of hepatitis was taken as resistance to lamivudine.

The study protocol was reviewed and approved by the Institutional Review Board of Hamad Medical Corporation.

\section{Statistical Methods}

Descriptive statistics in the form of mean, standard deviations, and range are calculated for interval variables, whereas counts and percentages are performed for categorical
TABLE 1: Demographic and clinical characteristics of the patients.

\begin{tabular}{lcc}
\hline & Number & Range \\
\hline Age & 40 & $27-79$ years \\
& & Mean 54 years \\
& & MD 8.94 \\
Gender & 40 & Female $32(80 \%)$ \\
HBSAg & 40 & $40 \%)$ \\
HBSAb & 40 & 32 positive $(100 \%)$ \\
HBeAg & 40 & 8 negative $(20 \%)$ \\
HBeAb & 40 & 25 positive $(62.5 \%)$ \\
& & 15 negative $(37.5 \%)$ \\
& & 15 positive $(37.5 \%)$ \\
\end{tabular}

TABLE 2: Biochemical and virological characteristics of the patient prior to treatment.

\begin{tabular}{lc}
\hline Disease duration & Years 5 (1-10) years \\
\hline ALT IU/L & $120(80-150) \mathrm{IU} / \mathrm{L}$ \\
Duration of treatment & 60 months \\
HBV DNA IU/mL & $2.0 \times 10^{3-10} \mathrm{IU} / \mathrm{mL}$ \\
Previous interferon therapy & 0 \\
\hline
\end{tabular}

variables. Kaplan Meier curve has been performed to see probability of not having resistance to lamivudine at different points of months. SPSS 20.0 Statistical Package is used for the analysis.

\section{Results}

The study population consists of 53 patients with chronic hepatitis B who were on lamivudine since June 2005. Out of 53 patients, 40 patients fulfilled the inclusion criteria. The mean age was 54 years with $80 \%$ being males. Fourteen patients (35\%) were from the state of Qatar and 26 patients (65\%) were expatriates. Twenty-five patients (62.5\%) were $\mathrm{HBeAg}+$ and 15 patients $(37.5 \%)$ were $\mathrm{HBeAg}$ - (Table 1 ). Before starting lamivudine treatment, all patients were having elevated liver enzyme ranging from 3 to 5 times the upper limit of normal and HBVDNA levels $>2,000 \mathrm{IU} / \mathrm{mL}$. Mean duration of lamivudine treatment was 60 months. None of the patients received interferon therapy or any other antiviral drug during this period. Seven patients had liver biopsy which was showing fibrosis stages 1 to 2 and inflammation grades 2 to 3 on Metavir Score system (Table 2).

All patients (Table 3) had biochemical normalization within 3 to 6 months of initiation of lamivudine therapy. Overall (87\%) patients were having a virological and biochemical response at 12 months of lamivudine treatment and 2 patients were having early viral breakthrough at 6 months after a partial HBV-DNA suppression. The response to lamivudine treatment was $77.4 \%$ at 24 months, $62.5 \%$ at 36 months, $50 \%$ at 48 months, and $40 \%$ at 60 months (Table 3 ).

There is progressive evolution of lamivudine resistance reaching up to $50 \%$ at 48 months and $60 \%$ at 60 months (Figure 1). Three patients achieved $\mathrm{HBeAg}$ seroconversion to 
TABLE 3: Treatment (biochemical and virological response).

\begin{tabular}{|c|c|c|c|c|c|}
\hline & $\begin{array}{c}12 \\
\text { months }\end{array}$ & $\begin{array}{c}24 \\
\text { months }\end{array}$ & $\begin{array}{c}36 \\
\text { months }\end{array}$ & $\begin{array}{c}48 \\
\text { months }\end{array}$ & $\begin{array}{c}60 \\
\text { Months }\end{array}$ \\
\hline $\begin{array}{l}\text { HBV DNA } \\
\text { IU/mL Below } \\
\text { detection level }\end{array}$ & $\begin{array}{c}35 / 40 \\
(87.5 \%)\end{array}$ & $\begin{array}{c}31 / 40 \\
(77.4 \%)\end{array}$ & $\begin{array}{c}25 / 40 \\
(62.5 \%)\end{array}$ & $\begin{array}{l}20 / 40 \\
(50 \%)\end{array}$ & $\begin{array}{l}16 / 40 \\
(40 \%)\end{array}$ \\
\hline $\begin{array}{l}\text { Biochemical } \\
\text { activity (high } \\
\text { ALT) }\end{array}$ & $2 / 40$ & normal & normal & normal & normal \\
\hline $\begin{array}{l}\text { HBsAg } \\
\text { seroconversion }\end{array}$ & $0 \%$ & $0 \%$ & $0 \%$ & $0 \%$ & $0 \%$ \\
\hline $\begin{array}{l}\mathrm{HBeAg} \\
\text { seroconversion }\end{array}$ & $0 \%$ & $0 \%$ & 1 & 2 & 3 \\
\hline $\begin{array}{l}\text { Viral } \\
\text { breakthrough }\end{array}$ & $\begin{array}{c}5 / 40 \\
(12.5 \%)\end{array}$ & $\begin{array}{c}9 / 40 \\
(22.5 \%)\end{array}$ & $\begin{array}{c}15 / 40 \\
(37.5 \%)\end{array}$ & $\begin{array}{l}20 / 40 \\
(50 \%)\end{array}$ & $\begin{array}{l}24 / 40 \\
(60 \%)\end{array}$ \\
\hline
\end{tabular}

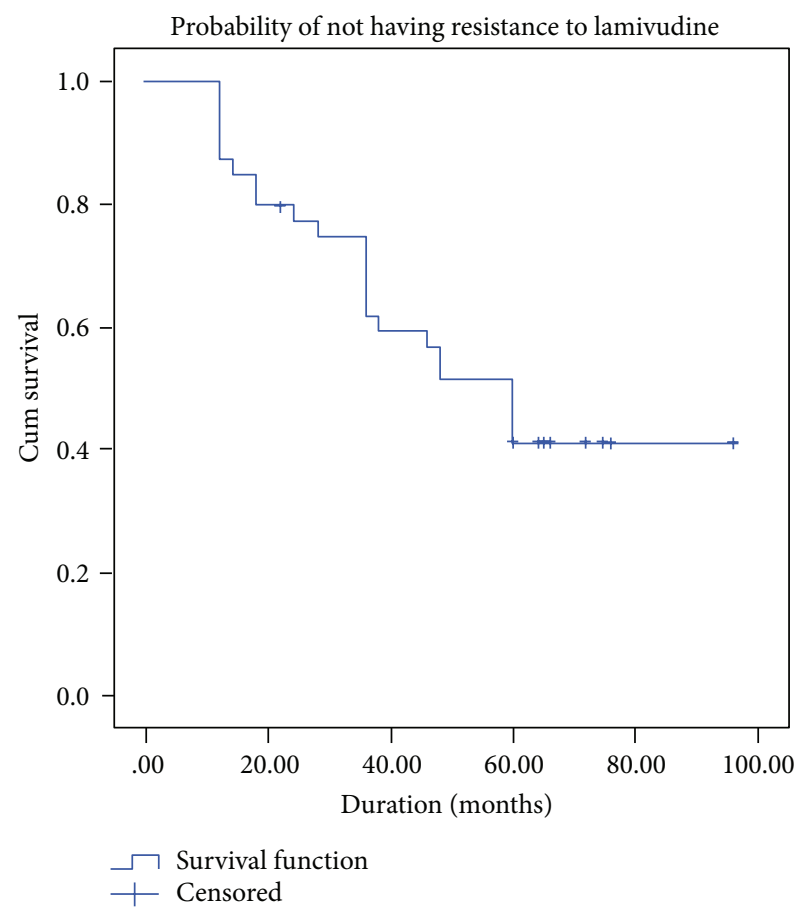

FIGURE 1: Kaplan-Meier curve showing probability of not having resistance to lamivudine.

anti-HBeAg, none had HBsAg seroconversion to antiHBs antibody positivity during these 5 years of treatment. Two patients died with multifocal hepatocellular carcinoma even after HBV-DNA suppression.

\section{Discussion}

Lamivudine was the first approved polymerase inhibitor for chronic hepatitis B. It is characterized by excellent tolerability with minimal or no side effects $[2,13]$. There is rapid development of antiviral resistance to the standard dose of $100 \mathrm{mg}$ of lamivudine in patients with chronic hepatitis B. Twenty (20\%) patients developed resistance within one year of treatment which can progress to 70 to $80 \%$ at 4 to 5 years $[6,14]$. The resistance rates have been higher in $\mathrm{HBeAg}$ positive patients $[15,16]$. HBsAg loss and seroconversion to anti-HBsAg antibody may occur spontaneously in 1-3\% of cases per year, usually after several years with persistently undetectable HBV DNA $[3,14]$.

In our study with the lamivudine dose of $150 \mathrm{mg}$ daily the resistance at 1 year was only $12.5 \%$ compared to 20 to $24 \%$ with standard lamivudine dose. The resistance was also delayed at 2 and 3 years with the $150 \mathrm{mg}$ lamivudine treatment and was $22.5 \%$ and $37.5 \%$ which is much less compared to the standard dose of $100 \mathrm{mg}$ of lamivudine. The main result of our study is that patients who received high dose of lamivudine have lower rate of resistance $(60 \%)$ over a mean duration of 60 months.

Torre et al. showed more profound suppression of viral replication with a lamivudine dose of $300 \mathrm{mg}$ once daily [17]. Ha et al. showed that an initial high dose of $300 \mathrm{mg}$ of lamivudine over a period of 2 weeks followed by $100 \mathrm{mg}$ daily, compared to standard dose, has a lower rate of resistance (60\% versus $76 \%)$ [18].

Adefovir, entecavir, and tenofovir are commonly used antivirals in patients with lamivudine resistance, although the development of the resistance is delayed and is less extent compared to lamivudine and telbivudine [19-21]. The lamivudine, even with dose of $150 \mathrm{mg}$, is safe in patients with end stage renal disease. Lamivudine mutations have been shown to confer cross-resistance to telbivudine, emtricitabine, and entecavir [22, 23].

The treatment endpoints of chronic hepatitis B are also not well defined. HBe antigen and hepatitis B surface antigen (HBsAg) seroconversion are markers of disease control and immunity. In our study, 7.5\% achieved HBeAg seroconversion but none had HBsAg seroconversion during these 5 years of lamivudine treatment.

Lamivudine is the most cost-effective treatment for the chronic HBV $[24,25]$. Although the new agents, like entecavir and tenofovir, appear more effective, they are more expensive than lamivudine. Selecting between these agents completely depends upon the available health care budget and willingness to pay. For poor patients, like in our study, who cannot afford the costly drugs, it appears more costeffective to start with lamivudine than adefovir and entecavir. In one meta-analysis of cost-effective strategy, 3/6 studies that evaluated the lamivudine against other drugs find it as a dominant strategy [26]. As recommended by current management guidelines, lamivudine once daily is used for an indefinite period in patients with cirrhosis [27-29].

The important limitation of our study is that being a retrospective study there is no other available group for the comparison; however, the objective of the study was to see the effect of high dose of lamivudine on the resistant pattern of chronic hepatitis B.

\section{Conclusions}

Our study showed that $150 \mathrm{mg}$ of lamivudine delayed the appearance of resistance in chronic hepatitis B. Lamivudine is very cheap compared to new antiviral drugs, has high safety profile, and has good compliance as compared to other new drugs. With this current available evidence, we consider that 
lamivudine as an antiviral treatment for chronic hepatitis B is a cost-effective intervention for many health care systems, including ours.

\section{Conflict of Interests}

The authors declare that there is no conflict of interests regarding the publication of this paper.

\section{References}

[1] N. Leung, "Treatment of chronic hepatitis B: case selection and duration of therapy," Journal of Gastroenterology and Hepatology, vol. 17, no. 4, pp. 409-414, 2002.

[2] T.-T. Chang, C.-L. Lai, R.-N. Chien et al., "Four years of lamivudine treatment in Chinese patients with chronic hepatitis B," Journal of Gastroenterology and Hepatology, vol. 19, no. 11, pp. 1276-1282, 2004.

[3] C. Pramoolsinsup, "Management of viral hepatitis B," Journal of Gastroenterology and Hepatology, vol. 17, no. 1, pp. S125-S145, 2002.

[4] L. Martín-Carbonero and E. Poveda, "Hepatitis B virus and HIV infection," Seminars in Liver Disease, vol. 32, no. 2, pp. 114-119, 2012.

[5] C. Wang, R. Fan, J. Sun, and J. Hou, "Prevention and management of drug resistant hepatitis B virus infections," Journal of Gastroenterology and Hepatology, vol. 27, no. 9, pp. 1432-1440, 2012.

[6] S. Manolakopoulos, S. Bethanis, J. Elefsiniotis et al., "Lamivudine monotherapy in HBeAg-negative chronic hepatitis B: prediction of response-breakthrough and long-term clinical outcome," Alimentary Pharmacology and Therapeutics, vol. 23, no. 6, pp. 787-795, 2006.

[7] Y. Tanaka, A. E. T. Yeo, E. Orito et al., "Prognostic indicators of breakthrough hepatitis during lamivudine monotherapy for chronic hepatitis B virus infection," Journal of Gastroenterology, vol. 39, no. 8, pp. 769-775, 2004.

[8] M.-J. Sheu, H.-T. Kuo, C.-Y. Lin et al., "Lamivudine monotherapy for chronic hepatitis B infection with acute exacerbation revisited," European Journal of Gastroenterology and Hepatology, vol. 21, no. 4, pp. 447-451, 2009.

[9] A. Tsubota, Y. Arase, Y. Suzuki et al., "Lamivudine monotherapy for spontaneous severe acute exacerbation of chronic hepatitis B," Journal of Gastroenterology and Hepatology, vol. 20, no. 3, pp. 426-432, 2005.

[10] L. J. Sun, J. W. Yu, Y. H. Zhao, P. Kang, and S. C. Li, "Influential factors of prognosis in lamivudine treatment for patients with acute-on-chronic hepatitis B liver failure," Journal of Gastroenterology and Hepatology, vol. 25, no. 3, pp. 583-590, 2010.

[11] M. Buti, F. Sánchez, M. Cotrina et al., "Quantitative hepatitis B virus DNA testing for the early prediction of the maintenance of response during lamivudine therapy in patients with chronic hepatitis B," Journal of Infectious Diseases, vol. 183, no. 8, pp. 1277-1280, 2001.

[12] T. Ide, R. Kumashiro, Y. Koga et al., "A real-time quantitative polymerase chain reaction method for hepatitis $\mathrm{B}$ virus in patients with chronic hepatitis B treated with lamivudine," The American Journal of Gastroenterology, vol. 98, no. 9, pp. 20482051, 2003.

[13] J. H. Kim, S. K. Yu, Y. S. Seo et al., "Clinical outcomes of chronic hepatitis B patients with persistently detectable serum hepatitis B virus DNA during lamivudine therapy," Journal of Gastroenterology and Hepatology, vol. 22, no. 8, pp. 1220-1225, 2007.

[14] S. K. Fung, F. Wong, M. Hussain, and A. S. F. Lok, "Sustained response after a 2-year course of lamivudine treatment of hepatitis B e antigen-negative chronic hepatitis B," Journal of Viral Hepatitis, vol. 11, no. 5, pp. 432-438, 2004.

[15] A. Marrone, R. Zampino, P. Karayannis et al., "Clinical reactivation during lamivudine treatment correlates with mutations in the precore/core promoter and polymerase regions of hepatitis $B$ virus in patients with anti-hepatitis B e-positive chronic hepatitis," Alimentary Pharmacology and Therapeutics, vol. 22, no. 8, pp. 707-714, 2005.

[16] P. Honkoop, H. G. M. Niesters, R. A. M. de Man, A. D. M. E. Osterhaus, and S. W. Schalm, "Lamivudine resistance in immunocompetent chronic hepatitis B: incidence and patterns," Journal of Hepatology, vol. 26, no. 6, pp. 1393-1395, 1997.

[17] F. Torre, E. G. Giannini, M. Basso, V. Fazio, V. Savarino, and A. Picciotto, "Initial high dose of lamivudine delays the appearance of viral resistance in chronic hepatitis B patients," Journal of Gastrointestinal and Liver Diseases, vol. 20, no. 1, pp. 47-50, 2011.

[18] M. Ha, G. Zhang, S. Diao et al., "Rescue therapy for lamivudineresistant chronic hepatitis B: adefovir monotherapy, adefovir plus lamivudine or entecavir combination therapy," Internal Medicine, vol. 51, no. 12, pp. 1509-1515, 2012.

[19] H. L. Y. Chan, Y. C. Chen, E. J. Gane et al., "Randomized clinical trial: efficacy and safety of telbivudine and lamivudine in treatment-naïve patients with HBV-related decompensated cirrhosis," Journal of Viral Hepatitis, vol. 19, no. 10, pp. 732-743, 2012.

[20] H. Jiang, J. Wang, and W. Zhao, "Lamivudine versus telbivudine in the treatment of chronic hepatitis B: a systematic review and meta-analysis," European Journal of Clinical Microbiology \& Infectious Diseases, vol. 32, no. 1, pp. 11-18, 2013.

[21] M. G. Peters, H. W. Hann, P. Martin et al., "Adefovir dipivoxil alone or in combination with lamivudine in patients with lamivudine-resistant chronic hepatitis B," Gastroenterology, vol. 126, no. 1, pp. 91-101, 2004.

[22] H. J. Kim, J. H. Park, D. I. Park et al., "Rescue therapy for lamivudine-resistant chronic hepatitis B: Comparison between entecavir $1.0 \mathrm{mg}$ monotherapy, adefovir monotherapy and adefovir add-on lamivudine combination therapy," Journal of Gastroenterology and Hepatology, vol. 25, no. 8, pp. 1374-1380, 2010.

[23] M. Sherman, C. Yurdaydin, H. Simsek et al., "Entecavir therapy for lamivudine-refractory chronic hepatitis B: improved virologie, biochemical, and serology outcomes through 96 weeks," Hepatology, vol. 48, no. 1, pp. 99-108, 2008.

[24] F. Kanwal, I. M. Gralnek, P. Martin, G. S. Dulai, M. Farid, and B. M. R. Spiegel, “Treatment alternatives for chronic hepatitis B virus infection: a cost-effectiveness analysis," Annals of Internal Medicine, vol. 142, no. 10, pp. 821-831, 2005.

[25] L. Solari, G. Hijar, R. Zavala, and J. M. Ureta, "Economic evaluation of antiviral treatment for chronic hepatitis B: a systematic review," Revista Peruana de Medicina Experimental y Salud Publica, vol. 27, no. 1, pp. 68-79, 2010.

[26] X. Sun, W.-X. Qin, Y.-P. Li, and X.-H. Jiang, "Comparative cost-effectiveness of antiviral therapies in patients with chronic hepatitis B: a systematic review of economic evidence," Journal of Gastroenterology and Hepatology, vol. 22, no. 9, pp. 1369-1377, 2007.

[27] C. Y. Peng, R. N. Chien, and Y. F. Liaw, "Hepatitis B virus-related decompensated liver cirrhosis: benefits of antiviral therapy," Journal of Hepatology, vol. 57, no. 2, pp. 442-450, 2012. 
[28] S. K. Fung and A. S. F. Lok, "Management of patients with hepatitis B virus-induced cirrhosis," Journal of Hepatology, vol. 42, no. 1, pp. S54-S64, 2005.

[29] E. B. Keeffe, D. T. Dieterich, S.-H. B. Han et al., "A treatment algorithm for the management of chronic hepatitis B virus infection in the United States," Clinical Gastroenterology and Hepatology, vol. 2, no. 2, pp. 87-106, 2004. 


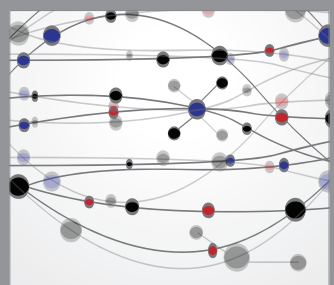

The Scientific World Journal
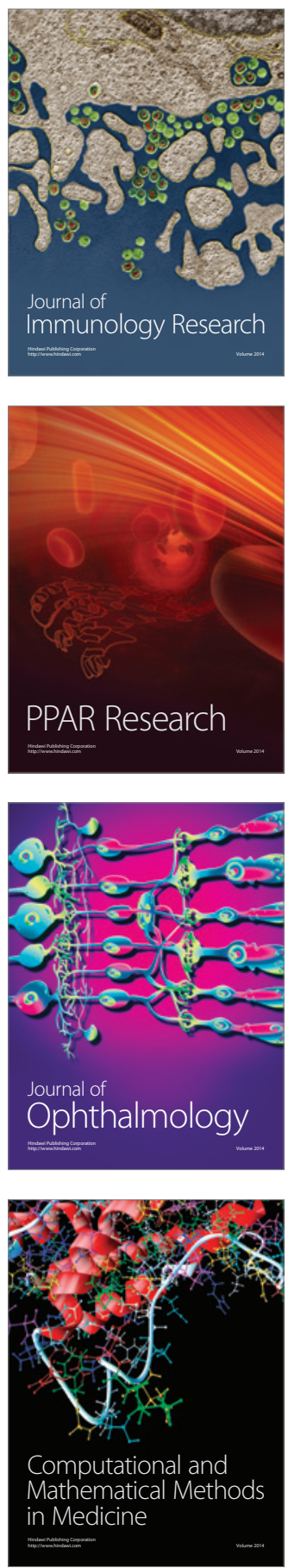

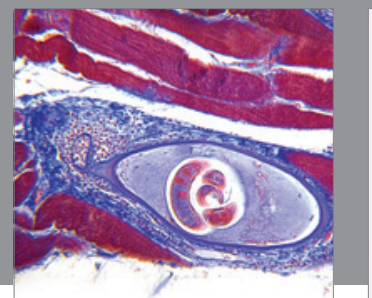

Gastroenterology

Research and Practice
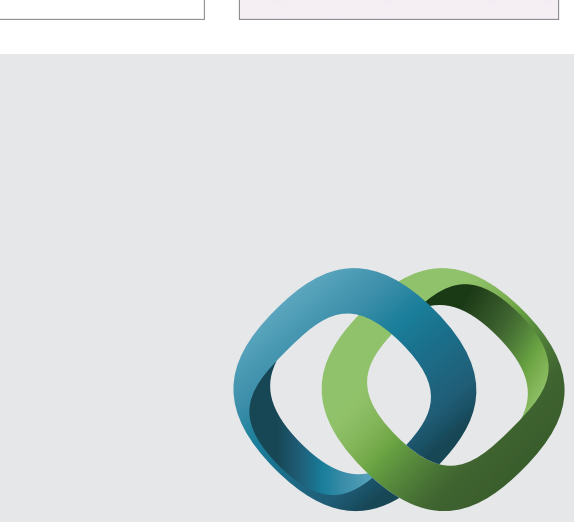

\section{Hindawi}

Submit your manuscripts at

http://www.hindawi.com
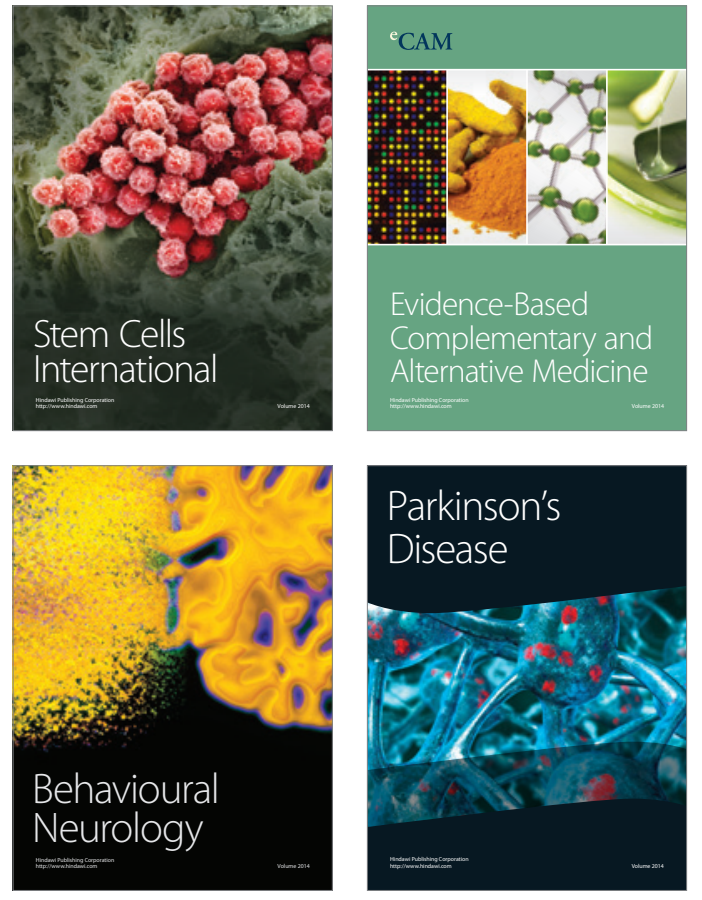
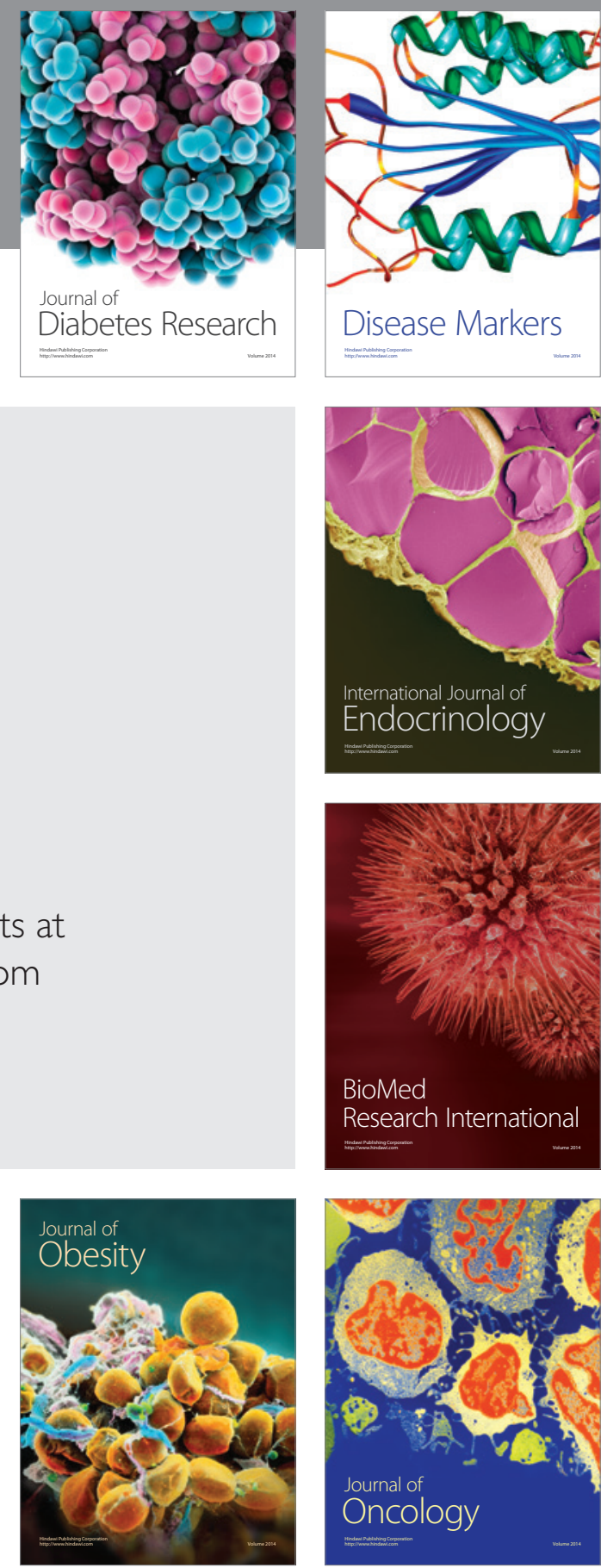

Disease Markers
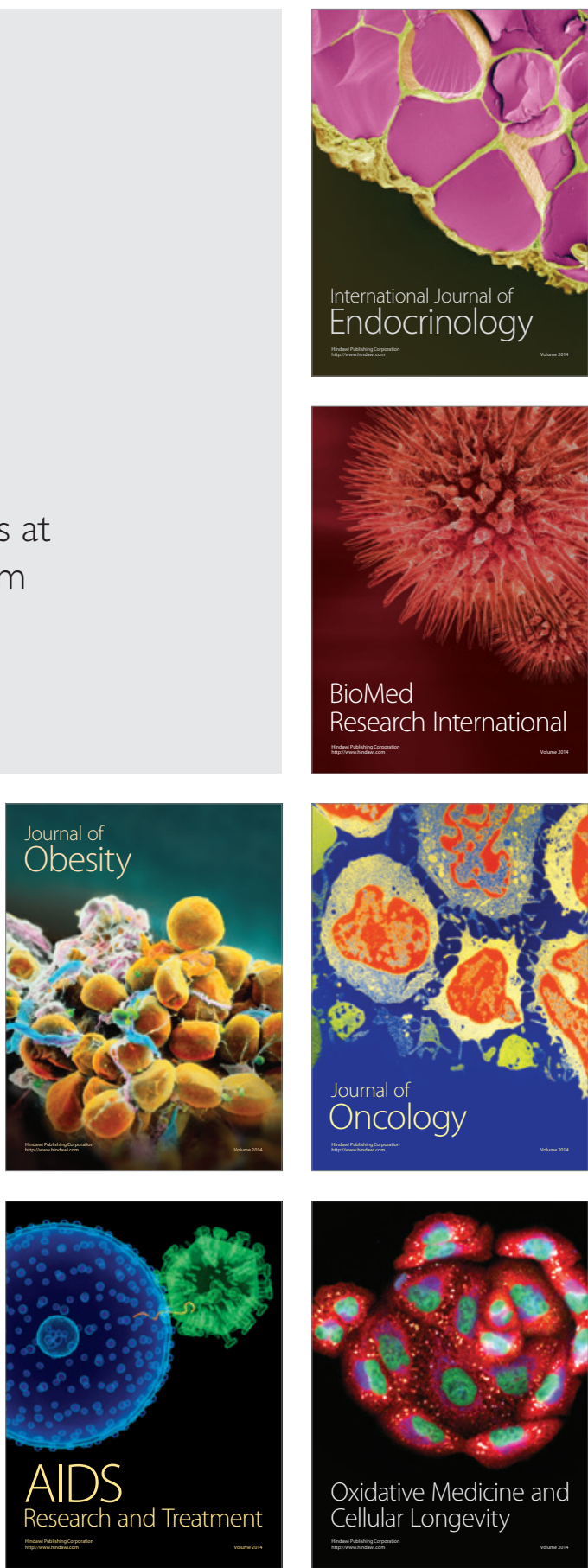